\title{
Pengaruh Penambahan Blondo Terhadap Karakteristik Flakes Tepung Beras Merah
}

\author{
Effect of Addition Blondo on Characteristics of Brown Rice Flour Flakes
}

\author{
Ridha Aulia Adha $^{1}$, Ni Made Yusa ${ }^{1 *}$, Ni Wayan Wisaniyasa ${ }^{1}$ \\ Program Studi Teknologi Pangan, Fakultas Teknologi Pertanian, Universitas Udayana \\ Kampus Bukit Jimbaran, Badung-Bali \\ *Penulis korespondensi: Ni Made Yusa, Email: madeyusa@unud.ac.id
}

\begin{abstract}
This study aims to determine the effect of addition of blondo on the characteristics of brown rice flakes and determine the appropriate addition of blondo to get the best brown rice flakes characteristics. The design used in this study was Completely Randomized Design with the treatment of adding blondo consisting of 6 levels, namely $0 \%$, 30\%, $40 \%, 50 \%, 60 \%$ and $70 \%$. This study was repeated three times to obtain 18 experimental units. The data obtained were analyzed by analysis of variance and if the treatment had a significant effect it was followed by DMRT (Duncan Multiple Range Test). The results showed that the addition of blondo had a significant effect on water content, protein content, fat content, carbohydrate content, crude fiber content, water absorption, aroma scoring test, taste scoring test and texture scoring test. Brown rice flakes with the addition of $40 \%$ blondo was the best treatment with characteristics water content $3.58 \%$, ash content $1.62 \%$, protein content $10.97 \%$, fat content $13.76 \%$, carbohydrate content $70.07 \%$, crude fiber content $4.21 \%$, water absorption $43.25 \%$, and color rather liked, aroma rather typical coconut and rather liked, taste rather typical coconut and rather liked, texture crispy and rather liked and overall acceptance rather liked.
\end{abstract}

Keywords: Brown rice flour, blondo, flakes

\section{PENDAHULUAN}

Dewasa ini banyak masyarakat yang menggemari hal serba instan, salah satunya yakni dalam memilih makanan. Makanan yang banyak digemari adalah makanan yang mudah cara penyajiannya seperti flakes. Flakes merupakan produk pangan yang berbentuk pipih dengan bagian tepi tidak rata, ringan, mudah disimpan, relatif tahan lama karena kadar airnya yang relatif rendah yakni $3-6 \%$ dan bertekstur renyah. Sugandhi (2016) mengatakan bahwa flakes umumnya berbahan dasar jagung dan gandum. Menurut Gisca dan Rahayuni, (2013) flakes merupakan produk breakfast cereal-ready yang penyajiannya cukup mudah yaitu dengan menambahkan cairan seperti susu ke dalamnya atau dapat juga dikonsumsi langsung serta dijadikan makanan tambahan bagi balita.

Produk flakes yang awalnya terbuat dari jagung dan gandum kini telah banyak dilakukan pengembangan. Seperti yang dilakukan oleh Rahmadani et al. (2016) membuat flakes dengan perbandingan kentang kukus dan terigu; Prianggi et al. (2016) membuat flakes dengan substitusi terigu dan buah lindur; Dewi et al. (2018) membuat flakes dengan menggunakan tepung kecambah millet; Utama et al. (2019) membuat flakes dengan substitusi terigu dan tepung kecambah jagung; Nindyawati et al. (2019) membuat flakes dengan perbandingan kentang kukus dan tepung kacang hijau dan juga Umar et al., (2018) yang membuat fakes dengan berbasis tepung beras merah dan sagu. 
Beras merah (Oryza nivara) merupakan bahan pangan pokok lain di Indonesia selain beras putih. Beras merah memiliki keunggulan pada kandungan serat dibandingkan dengan beras putih. Berdasarkan hasil penelitian Hernawan dan Melyani (2016) beras merah mengandung serat yang lebih tinggi dibandingkan dengan beras putih. Beras merah mengandung 12,58\% (bb) air, 1,61\% (bk) abu, 3,69\% (bk) lemak, 9,84\% (bk) protein dan $84,87 \%$ (bk) karbohidrat. Selain itu beras merah juga mengandung serat yang baik bagi kesehatan saluran pencernaan yaitu sebesar 7,54\% (bk) (Febriandi et al., 2017). Berdasarkan penelitian Umar et al. (2018) yang menggunakan tepung beras merah dalam pembuatan flakes dengan perbandingan tepung beras merah dengan sagu 90\% : 10\%, menghasilkan flakes yang mengandung $4,67 \%$ air, $2,38 \%$ abu, $12,58 \%$ protein, $17,98 \%$ lemak, serat $0,87 \%, 61,74 \%$ karbohidrat, energi sebesar 463,42 kkal, aktivitas antioksidan sangat kuat yakni $36,50 \mu \mathrm{g} / \mathrm{ml}$, daya serap air $112,83 \%$ dan nilai kesukaan panelis dengan kriteria agak suka. Penambahan bahan lain dapat dilakukan untuk meningkatkan nilai gizi dari flakes dan juga dapat meningkatkan nilai ekonomi dari bahan tersebut seperti dengan menambahkan blondo pada pembuatan flakes tepung beras merah.

Blondo merupakan hasil samping dari pembuatan minyak kelapa, memiliki berbagai sebutan di masing - masing daerah seperti galendo di Jawa Barat, tahi minyak di Sulawesi Selatan dan Sulawesi Barat, kethak di Jawa dan tlengis di Bali. Pembuatan minyak kelapa dengan cara pemanasan krim santan menghasilkan padatan blondo dan minyak kelapa (Diyah et al., 2010). Pembuatan
VCO menghasilkan blondo setelah krim santan ditambahkan asam asetat $25 \%$ atau minyak VCO atau enzim papain kemudian diinkubasi selama 12 jam (Setiaji dan Prayugo, 2006).

Dalam blondo masih terkandung nutrisi yang dibutuhkan oleh tubuh, seperti yang dilaporkan oleh Susanto (2012) bahwa dalam blondo terdeteksi asam amino esensial diantaranya yaitu metionin, valin, fenilalanin, isoleusin, leusin dan lisin. Selain itu dalam $100 \mathrm{~g}$ blondo juga mengandung protein $16,9 \mathrm{~g}$, lemak 23,9 g, karbohidrat 14,6 g, energi $341 \mathrm{kkal}$, serat 9,1 g, abu 1,4 g, air 16,9 g, vitamin A 0,1 RE, tiamin 0,1 mg, kobalamin $0,1 \mathrm{mg}$, asam folat $0,04 \mathrm{mg}$, kalsium $105,6 \mathrm{mg}$, fosfor $64,8 \mathrm{mg}$, besi $96,9 \mathrm{mg}$, seng 40,1 $\mu \mathrm{g}$, selenium 4,7 $\mu \mathrm{g}$, yodium $0,7 \mu \mathrm{g}$ (Widodo et al., 2007)

Pemanfaatan blondo menjadi pangan tradisional di Indonesia antara lain pesan tlengis dan plecing tlengis, campuran dalam pembuatan sambal kethak, dodol kethak atau campuran bumbu gudeg. Murtius (2008) melaporkan bahwa dalam blondo mengandung asam lemak esensial yaitu oleat, linoleat dan linolenat. Kandungan lemak pada blondo yang cukup tinggi, dapat menjadikan blondo sebagai pensubstitusi lemak pada pembuatan produk pangan seperti yang telah dilakukan Widodo (2015) yang menggunakan blondo sebagai pensubstitusi margarin pada pembuatan biskuit dimana perbandingan blondo dan margarin 50\% : 50\% menghasilkan biskuit yang mendapatkan nilai uji organoleptik terbaik.

Tingginya gizi yang terkandung dalam blondo, banyak menarik peneliti untuk mengembangkan pemanfaatan blondo seperti 
campuran dalam pembuatan biskuit, sebagai starter pembuatan yogurt dan campuran dalam pembuatan kue kering, namun belum ditemukan pemanfaatan blondo sebagai bahan dalam pembuatan flakes. Maka dari itu dilakukan penelitian mengenai pengaruh penambahan blondo terhadap karakteristik flakes tepung beras merah.

\section{METODE PENELITIAN}

\section{Tempat dan Waktu}

Penelitian ini dilaksanakan di

Laboratorium Pengolahan Pangan, Laboratorium Analisis Pangan dan Laboratorium Pasca Panen.

Gedung Agrokomplek lantai III Fakultas Teknologi Pertanian Universitas Udayana. Alamat Jl, P.B. Sudirman, Denpasar, Bali. Pelaksanaan Penelitian dilaksanakan pada bulan Agustus sampai dengan bulan September 2020.

\section{Bahan dan Alat}

Bahan - bahan yang digunakan dalam penelitian ini adalah blondo yang diperoleh di Pasar Cokroaminoto Denpasar, beras merah (Seblang Banyuwangi) yang diperoleh di Toko Bali Jaya serta gula halus (Claris), margarin (Forvita), vanili bubuk (Koepoe-koepoe), garam (Dolpin), air (Aqua) dan susu skim bubuk yang diperoleh dari toko UD. Fenny, Denpasar. Bahan kimia yang digunakan untuk analisis antara lain H2SO4 (Merck), NaOH teknis \& PA (Merck), HCL (Merck), indikator Phenolphtalein (Merck), asam borat (Merck), bubuk Kjeldahl PA (Merck), N-Heksan teknis (Merck), alkohol 96\% (Merck) dan aquades.

Alat yang digunakan adalah timbangan analitik (Shimadzu ATY224), oven (Labo Do 225), loyang, aluminium foil, blender (Phillips), ayakan 80 mesh (Retsch), baskom, kain saring, pisau stainless steel, sendok, penggiling adonan kayu, wadah plastik, serta alat untuk analisis antara lain tabung reaksi, gelas ukur, gelas beker, kertas saring, corong, pipet tetes, cawan, soxhlet, buret, desikator, hot plate, kertas whatman 42, tanur, corong kaca, pemanas listrik, pipet volume, labu takar, pompa karet, destilator dan erlenmeyer.

\section{Rancangan Penelitian}

Rancangan percobaan yang digunakan pada penelitian ini adalah Rancangan Acak Lengkap (RAL) dengan perlakuan penambahan blondo yang terdiri dari 6 taraf, yaitu P0 (Penambahan Blondo 0\%), P1 (Penambahan Blondo 30\%), P2 (Penambahan Blondo 40\%), P3 (Penambahan Blondo 50\%), P4 (Penambahan Blondo 60\%) dan P5 (Penambahan Blondo 70\%). Masing-masing perlakuan diulang sebanyak 3 kali sehingga diperoleh 18 unit percobaan. Data yang diperoleh dianalisis dengan sidik ragam dan apabila perlakuan berpengaruh terhadap variabel yang diamati maka dilanjutkan dengan Uji Duncan's Multiple Range Test (DMRT) (Gomez dan Gomez, 1995).

\section{Parameter yang diamati}

Variabel yang diamati pada penelitian ini adalah kadar air dengan metode pengeringan (Sudarmadji et al., 1997) kadar abu dengan metode pengabuan kering (Sudarmadji et al., 1997), kadar protein dengan metode mikro kjeldahl (Sudarmadji et al., 1997), kadar lemak dengan metode soxhlet (Sudarmadji et al., 1997), kadar karbohodrat dengan metode by difference dan serat kasar dengan metode hidrolisis asam basa (Sudarmadji et 
al., 1997), daya serap air flakes berdasarkan Dewi (2008), serta sifat sensoris yang meliputi uji skoring (aroma, rasa dan tekstur) dan uji hedonik (warna, aroma, rasa, tekstur dan penerimaan keseluruhan) berdasarkan Soekarto (1985).

\section{Pelaksanaan Penelitian}

\section{Proses Pembuatan Tepung Beras Merah}

Beras merah dibersihkan dari gabah dan kotoran. Selanjutnya dicuci lalu ditiriskan. Kemudian dikeringkan dalam oven pada suhu $50^{\circ} \mathrm{C}$ selama 2 jam. Tahapan selanjutnya dihaluskan dengan menggunakan blender dan diayak dengan menggunakan ayakan 80 mesh (Purba et al., 2017).

Tabel 1. Formulasi flakes tepung beras merah

\begin{tabular}{ccccccc}
\hline Komposisi Bahan & \multicolumn{7}{c}{ Perlakuan } \\
\cline { 2 - 6 } & P0 & P1 & P2 & P3 & P4 & P5 \\
\hline Tepung beras merah (g) & 100 & 100 & 100 & 100 & 100 & 100 \\
Blondo (\%) & 0 & 30 & 40 & 50 & 60 & 70 \\
Gula (\%) & 20 & 20 & 20 & 20 & 20 & 20 \\
Garam (\%) & 0,5 & 0,5 & 0,5 & 0,5 & 0,5 & 0,5 \\
Margarin (\%) & 10 & 10 & 10 & 10 & 10 & 10 \\
Susu skim bubuk (\%) & 25 & 25 & 25 & 25 & 25 & 25 \\
Vanilli (\%) & 0,5 & 0,5 & 0,5 & 0,5 & 0,5 & 0,5 \\
Air (\%) & 20 & 20 & 20 & 20 & 20 & 20 \\
\hline
\end{tabular}

Sumber: Umar et al. (2018) yang dimodifikasi.

Keterangan: Persentase dihitung berdasarkan berat tepung beras merah.

\section{HASIL DAN PEMBAHASAN}

\section{Hasil Analisis Bahan Baku}

\section{Proses Pembuatan Flakes Tepung Beras Merah}

Proses pembuatan flakes tepung baras merah mengacu pada penelitian Umar, et al. (2018) yang dimodifikasi dengan penambahan blondo pada flakes tepung beras merah. Proses pembuatan flakes tepung beras merah diawali dengan penambahan blondo pada tepung beras merah sesuai perlakuan dan masing-masing perlakuan ditambahkan gula, garam, margarin, susu skim bubuk, vanili, dan air. Selanjutnya bahan diuleni hingga kalis. Adonan dipipihkan menjadi bentuk flakes dengan ketebalan $\pm 1 \mathrm{~mm}$. Selanjutnya dikeringkan dengan menggunakan oven pada suhu $150^{\circ} \mathrm{C}$ selama 20 menit. Formulasi flakes tepung beras merah disajikan pada Tabel 1 .

\section{Hasil Analisis Flakes Tepung Beras Merah}

Nilai rata-rata hasil analisis kadar air, kadar abu, kadar protein dan kadar lemak flakes tepung beras merah dapat dilihat pada Tabel 3 serta kadar karbohidrat, kadar serat kasar dan daya serap air flakes tepung beras merah dapat dilihat pada Tabel 4. 
Tabel 2. Hasil analisis tepung beras merah dan blondo

\begin{tabular}{ccc}
\hline Komponen \%(bb) & Tepung Beras Merah & Blondo \\
\hline Kadar Air & $10,15 \%$ & $40,88 \%$ \\
Kadar Abu & $1,30 \%$ & $0,65 \%$ \\
Kadar Protein & $11,27 \%$ & $12,14 \%$ \\
Kadar Lemak & $9,98 \%$ & $19,10 \%$ \\
Kadar Karbohidrat & $67,29 \%$ & $27,24 \%$ \\
Kadar Serat Kasar & $6,53 \%$ & $11,30 \%$ \\
\hline
\end{tabular}

Tabel 3. Nilai rata-rata kadar air, kadar abu, kadar protein, dan kadar lemak dari flakes tepung beras merah dengan penambahan blondo

\begin{tabular}{ccccc}
\hline $\begin{array}{c}\text { Perlakuan } \\
\text { Penambahan Blondo }\end{array}$ & Kadar Air (\%bb) & Kadar Abu (\%bb) & Kadar Protein (\%bb) & Kadar Lemak (\%bb) \\
\hline P0 (0\%) & $2,65 \pm 0,18 \mathrm{e}$ & $1,42 \pm 0,15 \mathrm{c}$ & $9,68 \pm 0,48 \mathrm{e}$ & $9,79 \pm 0,03 \mathrm{e}$ \\
P1 (30\%) & $3,25 \pm 0,17 \mathrm{~d}$ & $1,56 \pm 0,03 \mathrm{~b}$ & $10,45 \pm 0,14 \mathrm{~d}$ & $12,70 \pm 0,33 \mathrm{~d}$ \\
P2 (40\%) & $3,58 \pm 0,13 \mathrm{~d}$ & $1,62 \pm 0,02 \mathrm{~b}$ & $10,97 \pm 0,15 \mathrm{~d}$ & $13,76 \pm 0,07 \mathrm{c}$ \\
P3 (50\%) & $4,06 \pm 0,31 \mathrm{c}$ & $1,65 \pm 0,01 \mathrm{ab}$ & $11,56 \pm 0,30 \mathrm{c}$ & $14,10 \pm 0,05 \mathrm{c}$ \\
P4 (60\%) & $4,64 \pm 0,21 \mathrm{~b}$ & $1,66 \pm 0,01 \mathrm{ab}$ & $12,31 \pm 0,37 \mathrm{~b}$ & $15,03 \pm 0,17 \mathrm{~b}$ \\
P5 (70\%) & $5,15 \pm 0,08 \mathrm{a}$ & $1,75 \pm 0,04 \mathrm{a}$ & $13,41 \pm 0,19 \mathrm{a}$ & $17,28 \pm 0,68 \mathrm{a}$ \\
\hline
\end{tabular}

Keterangan: Nilai rata-rata yang diikuti oleh huruf yang berbeda pada kolom yang sama menunjukkan perlakuan yang berbeda nyata $(\mathrm{P}<0,05)$.

Tabel 4. Nilai rata-rata kadar karbohidrat, kadar serat kasar dan daya serap air dari flakes tepung beras merah dengan penambahan blondo

\begin{tabular}{cccc}
\hline $\begin{array}{c}\text { Perlakuan } \\
\text { Penambahan Blondo }\end{array}$ & $\begin{array}{c}\text { Kadar Karbohidrat } \\
(\% \mathrm{bb})\end{array}$ & $\begin{array}{c}\text { Kadar Serat Kasar } \\
(\% \mathrm{bb})\end{array}$ & Daya Serap Air $(\%)$ \\
\hline P0 $(0 \%)$ & $76,46 \pm 0,32 \mathrm{a}$ & $1,98 \pm 0,30 \mathrm{e}$ & $79,94 \pm 0,07 \mathrm{a}$ \\
P1 $(30 \%)$ & $72,04 \pm 0,57 \mathrm{~b}$ & $3,06 \pm 0,13 \mathrm{~d}$ & $50,44 \pm 0,06 \mathrm{~b}$ \\
P2 (40\%) & $70,07 \pm 0,10 \mathrm{c}$ & $4,21 \pm 0,16 \mathrm{c}$ & $43,25 \pm 0,16 \mathrm{c}$ \\
P3 $(50 \%)$ & $68,63 \pm 0,60 \mathrm{~d}$ & $4,87 \pm 0,35 \mathrm{~b}$ & $36,04 \pm 0,04 \mathrm{~d}$ \\
P4 (60\%) & $66,36 \pm 0,16 \mathrm{e}$ & $5,26 \pm 0,58 \mathrm{~b}$ & $32,75 \pm 0,07 \mathrm{e}$ \\
P5 (70\%) & $62,41 \pm 0,93 \mathrm{f}$ & $5,92 \pm 0,44 \mathrm{a}$ & $30,14 \pm 0,77 \mathrm{f}$ \\
\hline
\end{tabular}

Keterangan: Nilai rata-rata yang diikuti oleh huruf yang berbeda pada kolom yang sama menunjukkan perlakuan yang berbeda nyata $(\mathrm{P}<0,05)$.

\section{Kadar Air}

Hasil sidik ragam menunjukkan bahwa penambahan blondo berpengaruh nyata $(\mathrm{P}<0,05)$ terhadap kadar air flakes tepung beras merah. Pada Tabel 3 dapat dilihat bahwa kadar air tertinggi terdapat pada perlakuan penambahan blondo $70 \%$ yakni sebesar $5,15 \%$, sedangkan kadar air terendah terdapat pada penambahan blondo $0 \%$ yakni sebesar $2,65 \%$.
Kadar air flakes tepung beras merah meningkat seiring dengan meningkatnya penambahan blondo. Kadar air yang tinggi disebabkan oleh kadar air yang terkandung pada blondo tinggi, yakni sebesar 40,88\%. Kandungan air yang tinggi pada blondo mengakibatkan kadar air dalam adonan tidak banyak menguap saat pengolahan, sehingga setelah proses pengolahan masih terdapat cukup banyak air yang terkandung. Komala et al. (2017) mengatakan bahwa semakin 
tinggi penambahan tepung ampas kelapa yang memiliki kandungan serat kasar tinggi menghasilkan flakes dengan kadar air yang semakin meningkat. Hal tersebut dikarenakan selulosa yang termasuk dalam serat kasar merupakan polisakarida yang disusun oleh Dglukosa yang mempunyai tiga gugus hidroksil. Gugus - $\mathrm{OH}$ akan mengikat gugus $-\mathrm{H}$ air dan membentuk ikatan hidrogen. Gugus $-\mathrm{OH}$ pada selulosa menyebabkan selulosa menjadi hidrofilik. Semakin banyaknya blondo yang ditambahkan akan meningkatkan jumlah air yang diserap dan jumlah air yang tertinggal setelah proses pengeringan juga lebih banyak. Nilai rata-rata kadar air pada perlakuan penambahan blondo $0 \%$ dan 30\% telah memenuhi syarat mutu flakes SNI 01-4270-1996, yaitu maksimal 3\% bb.

\section{Kadar Abu}

Hasil sidik ragam menunjukkan bahwa perlakuan penambahan blondo berpengaruh nyata $(\mathrm{P}<0,05)$ terhadap kadar abu flakes tepung beras merah. Pada Tabel 3 dapat dilihat bahwa flakes dengan kadar abu tertinggi yaitu pada perlakuan penambahan blondo $70 \%$ yakni 1,75\% dan kadar abu terendah yaitu pada perlakuan penambahan blondo $0 \%$ yakni sebesar $1,42 \%$.

Kadar abu pada flakes tepung beras merah meningkat seiring dengan meningkatnya penambahan konsentrasi blondo. Kadar abu yang tinggi dikarenakan abu yang terkandung dalam blondo. Blondo yang digunakan pada penelitian ini mengandung abu sebesar $0,65 \%$. Hal ini sesuai dengan pernyataan Tahir et.al. (2018) yang mengatakan bahwa penambahan blondo yang semakin meningkat, menghasilkan kue kering dengan kadar abu yang semakin tinggi. Kadar abu menunjukkan bahwa adanya kandungan mineral dalam suatu pangan. Seperti yang dikatakan dalam deMan (1997) bahwa pengabuan atau insinerasi biasanya digunakan untuk menentukan mineral dalam makanan. Hasil penelitian menunjukkan bahwa nilai rata-rata kadar abu pada semua perlakuan penambahan blondo telah memenuhi syarat mutu flakes SNI 01-4270-1996, yaitu maksimal 4\% bb.

\section{Kadar Protein}

Hasil sidik ragam menunjukkan bahwa penambahan blondo berpengaruh nyata $(\mathrm{P}<0,05)$ terhadap kadar protein flakes tepung beras merah. Dapat dilihat pada Tabel 3 kadar protein yang tertinggi terdapat pada perlakuan penambahan blondo $70 \%$ yakni sebesar $13,41 \%$, sedangkan kadar protein yang terendah terdapat pada perlakuan penambahan blondo $0 \%$ yakni sebesar $9,68 \%$.

Kadar protein flakes tepung beras merah meningkat seiring dengan meningkatnya penambahan blondo.. Hal tersebut bisa dikarenakan kandungan protein dalam blondo yang tinggi. Kadar protein pada blondo yang digunakan dalam penelitian ini sebesar $12,14 \%$. Protein tersusun atas berbagai macam asam amino. Susanto (2012) melaporkan bahwa dalam blondo terdapat asam amino esensial diantaranya metionin, valin, fenilalanin, isoleusin, leusin dan lisin. Hasil penelitian menunjukkan bahwa nilai rata-rata kadar protein pada semua perlakuan 
penambahan blondo telah memenuhi syarat mutu flakes SNI 01-4270-1996, yaitu minimal 5\% bb.

\section{Kadar Lemak}

Hasil sidik ragam menunjukkan bahwa penambahan blondo berpengaruh nyata $(\mathrm{P}<0,05)$ terhadap kadar lemak flakes tepung beras merah. Kadar lemak yang tertinggi terdapat pada perlakuan penambahan blondo 70\% yakni 17,28\%, sedangkan kadar lemak terendah terdapat pada perlakuan penambahan blondo $0 \%$ yakni $9,79 \%$.

Kadar lemak pada flakes tepung beras merah meningkat seiring dengan meningkatnya konsentrasi blondo yang ditambahkan. Kadar lemak yang tinggi dikarenakan kandungan lemak pada blondo yang digunakan tinggi, yakni sebesar $19,10 \%$. Oleh karena itu semakin banyak blondo yang ditambahkan maka semakin tinggi kadar lemak pada flakes tepung beras merah. Selain blondo, beberapa bahan yang digunakan pada pembuatan flakes tepung beras merah juga mempengaruhi kandungan lemak. Bahan tersebut yaitu tepung beras merah, margarin dan susu skim. Kandungan lemak pada bahan-bahan tersebut antara lain tepung beras merah 9,98\%, margarin $81 \%$, susu skim bubuk 1\% (Anon., 2018). Hasil penelitian menunjukkan bahwa nilai rata-rata kadar lemak pada semua perlakuan penambahan blondo telah memenuhi syarat mutu flakes SNI 01-42701996, yaitu minimal 7\% bb.

\section{Kadar Karbohidrat}

Hasil sidik ragam menunjukkan bahwa penambahan blondo berpengaruh nyata $(\mathrm{P}<0,05)$ terhadap kadar karbohidrat flakes tepung beras merah . Kadar karbohidrat flakes tepung beras merah yang tertinggi terdapat pada perlakuan penambahan blondo $0 \%$ yaitu $76,46 \%$, sedangkan kadar karbohidrat yang terendah terdapat pada perlakuan penambahan blondo $70 \%$ yaitu sebesar $62,41 \%$.

Kadar karbohidrat dihitung dengan cara $b y$ difference yaitu $100 \%$ dikurangi \% kadar air, \% kadar abu, \% kadar protein dan \% kadar lemak. Persentase kadar karbohidrat pada flakes tepung beras merah berkurang seiring dengan banyaknya konsentrasi blondo yang ditambahkan. Hal tersebut dikarenakan semakin banyaknya blondo yang ditambahkan, kandungan nutrisi lainnya yaitu kadar air, kadar abu, kadar protein serta kadar lemak flakes tepung beras merah meningkat, sehingga persentase kadar karbohidrat menurun. Hasil penelitian menunjukkan bahwa nilai rata-rata kadar karbohidrat pada semua perlakuan penambahan blondo telah memenuhi syarat mutu flakes SNI 01-4270-1996 yakni minimal 60,7\% bb.

\section{Kadar Serat Kasar}

Hasil sidik ragam menunjukkan bahwa penambahan blondo berpengaruh nyata $(\mathrm{P}<0,05)$ terhadap kadar serat kasar flakes tepung beras merah. Serat kasar yang tertinggi terdapat pada perlakuan penambahan blondo $70 \%$ yakni sebesar $5,92 \%$, sedangkan yang terendah terdapat pada perlakuan penambahan blondo $0 \%$ yakni 1,98\%.

Kandungan serat kasar pada flakes tepung beras merah meningkat seiring dengan meningkatnya konsentrasi blondo yang ditambahkan. Tingginya serat kasar pada flakes tepung beras merah diduga karena tingginya kadar 
serat kasar pada blondo yang digunakan, sehingga semakin banyaknya blondo yang ditambahkan, kadar serat flakes tepung beras merah juga turut meningkat. Selain blondo, tepung beras merah juga memberikan pengaruh terhadap kadar serat kasar. Kandungan serat kasar pada blondo yaitu sebesar $11,30 \%$ lebih besar dibandingkan dengan kadar serat kasar tepung beras merah yaitu $6,53 \%$. Serat mempunyai beberapa manfaat bagi kesehatan antara lain yaitu mengontrol berat badan, menanggulangi diabetes, mencegah gangguan gastrointestinal, mencegah kanker usus besar serta mengurangi tingkat kolesterol dan penyakit kardiovaskuler (Santoso, 2011). Hasil penelitian menunjukkan bahwa nilai rata-rata kadar serat kasar pada semua perlakuan penambahan blondo tidak memenuhi syarat mutu flakes SNI 01-42701996, yakni maksimal 0,7\% bb.

\section{Daya Serap Air}

Hasil sidik ragam menunjukkan bahwa penambahan blondo berpengaruh nyata $(\mathrm{P}<0,05)$ terhadap daya serap air dari flakes tepung beras merah. Daya serap air tertinggi terdapat pada perlakuan penambahan blondo $0 \%$ yakni sebesar $79,94 \%$, sedangkan daya serap air yang terendah terdapat pada perlakuan penambahan blondo $70 \%$ yakni sebesar $30,14 \%$.

Uji daya serap air dilakukan untuk mengetahui kemampuan flakes tepung beras merah dalam menyerap air. Makanan berjenis ready to eat harus mampu mempertahankan kerenyahannya saat disajikan bersama dengan susu (Gandhi et.al., (2012) dan Baik et.al. (2004)). Flakes yang baik merupakan flakes dengan daya ikat air yang rendah, karena mampu mempertahankan kerenyahan lebih baik. Daya serap air flakes tepung beras merah menurun seiring dengan semakin banyaknya blondo yang ditambahkan. Daya serap air dipengaruhi oleh kandungan pati dan serat. Pembuatan flakes pada penelitian ini menggunakan bahan baku tepung beras merah, dimana tepung beras merah mengandung pati $\pm 76,49 \%$ (Febriandi et al., 2017) dan serat kasar sebesar 6,53\%. Blondo yang ditambahkan dalam penelitian ini juga mengandung serat kasar sebesar 11,30\%. Penambahan blondo yang semakin meningkat, menghasilkan flakes dengan kadar serat kasar yang meningkat pula. Kandungan serat yang tinggi pada suatu bahan akan menghasilkan nilai penyerapan air yang tinggi (Richana dan Sunarti, 2004). Namun pada penelitian ini daya serap air flakes dengan semakin banyaknya blondo yang ditambahkan, terjadi penurunan daya serap air. Hal tersebut diduga terjadi karena semakin banyaknya penambahan blondo juga semakin meningkatkan kandungan lemak pada flakes tepung beras merah. Blondo mengandung lemak sebesar 19,10\%. Lemak bersifat hidrofobik yaitu tidak dapat larut dengan air, oleh karena itu diduga kandungan lemak yang semakin meningkat, menghalangi penyerapan air saat analisis daya serap air sehingga air yang mampu diserap semakin berkurang (Kusnandar, 2010 dalam Permana dan Putri, 2015).

\section{Evaluasi Senrosis Flakes Tepung Beras Merah}

Evaluasi sensoris flakes tepung beras merah dilakukan dengan uji hedonik terhadap warna, aroma, rasa, tekstur dan penerimaan keseluruhan, serta uji skoring dilakukan terhadap aroma, rasa dan tekstur. Nilai rata-rata uji hedonik 
disajikan dalam Tabel 5. Nilai rata-rata uji skoring

disajikan dalam Tabel 6.

Tabel 5. Nilai rata-rata uji hedonik warna, aroma, rasa, tekstur dan penerimaan keseluruhan flakes tepung beras merah

\begin{tabular}{cccccc}
\hline $\begin{array}{c}\text { Perlakuan } \\
\text { Penambahan } \\
\text { Blondo }\end{array}$ & Warna & Aroma & Rasa & Tekstur & $\begin{array}{c}\text { Penerimaan } \\
\text { Keseluruhan }\end{array}$ \\
\hline P0 (0\%) & $4,28 \pm 1,10 \mathrm{a}$ & $3,72 \pm 1,10 \mathrm{a}$ & $3,72 \pm 1,21 \mathrm{ab}$ & $4,00 \pm 1,22 \mathrm{ab}$ & $3,76 \pm 1,16 \mathrm{a}$ \\
P1 (30\%) & $4,16 \pm 0,90 \mathrm{a}$ & $3,80 \pm 1,15 \mathrm{a}$ & $3,24 \pm 1,13 \mathrm{~b}$ & $4,12 \pm 1,01 \mathrm{a}$ & $3,68 \pm 1,11 \mathrm{a}$ \\
P2 (40\%) & $3,68 \pm 0,99 \mathrm{ab}$ & $3,72 \pm 1,14 \mathrm{a}$ & $3,60 \pm 1,19 \mathrm{ab}$ & $4,16 \pm 1,03 \mathrm{a}$ & $4,00 \pm 0,96 \mathrm{a}$ \\
P3 (50\%) & $3,84 \pm 0,99 \mathrm{a}$ & $3,48 \pm 0,92 \mathrm{a}$ & $3,68 \pm 1,11 \mathrm{ab}$ & $3,44 \pm 1,23 \mathrm{~b}$ & $3,72 \pm 0,98 \mathrm{a}$ \\
P4 (60\%) & $3,80 \pm 0,87 \mathrm{a}$ & $3,72 \pm 1,02 \mathrm{a}$ & $4,00 \pm 0,91 \mathrm{a}$ & $3,88 \pm 0,88 \mathrm{ab}$ & $3,64 \pm 0,81 \mathrm{a}$ \\
P5 (70\%) & $3,16 \pm 1,18 \mathrm{~b}$ & $3,72 \pm 0,79 \mathrm{a}$ & $3,72 \pm 1,06 \mathrm{ab}$ & $3,64 \pm 1,11 \mathrm{ab}$ & $3,44 \pm 0,96 \mathrm{a}$ \\
\hline
\end{tabular}

Keterangan: Nilai rata-rata yang diikuti oleh huruf yang berbeda pada kolom yang sama menunjukkan perlakuan yang berbeda nyata $(\mathrm{P}<0,05)$.

Kriteria hedonik: 1 (tidak suka), 2 (agak tidak suka), 3 (biasa), 4 (agak suka), 5 (suka).

Tabel 6. Nilai rata-rata uji skoring flakes tepung beras merah

\begin{tabular}{cccc}
\hline $\begin{array}{c}\text { Perlakuan Penambahan } \\
\text { Blondo }\end{array}$ & Skoring Aroma & Skoring Rasa & Skoring Tekstur \\
\hline P0 (0\%) & $2,40 \pm 0,96 \mathrm{c}$ & $2,08 \pm 1,00 \mathrm{~d}$ & $4,96 \pm 0,20 \mathrm{a}$ \\
P1 (30\%) & $2,80 \pm 0,96 \mathrm{c}$ & $2,68 \pm 0,99 \mathrm{c}$ & $4,68 \pm 0,56 \mathrm{ab}$ \\
P2 (40\%) & $3,44 \pm 0,87 \mathrm{~b}$ & $3,04 \pm 0,84 \mathrm{c}$ & $4,40 \pm 0,64 \mathrm{bc}$ \\
P3 (50\%) & $3,72 \pm 0,94 \mathrm{~b}$ & $3,72 \pm 0,61 \mathrm{~b}$ & $3,96 \pm 0,84 \mathrm{~cd}$ \\
P4 (60\%) & $4,36 \pm 0,70 \mathrm{a}$ & $4,28 \pm 0,61 \mathrm{a}$ & $3,56 \pm 1,08 \mathrm{~d}$ \\
P5 (70\%) & $4,68 \pm 0,63 \mathrm{a}$ & $4,52 \pm 0,58 \mathrm{a}$ & $2,84 \pm 1,14 \mathrm{e}$ \\
\hline
\end{tabular}

Keterangan: Nilai rata-rata yang diikuti oleh huruf yang berbeda pada kolom yang sama menunjukkan perlakuan yang berbeda nyata $(\mathrm{P}<0,05)$.

Kriteria skoring aroma dan rasa: 1 (sangat tidak khas kelapa), 2 (tidak khas kelapa), 3 (agak khas kelapa), 4 (khas kelapa), 5 (sangat khas kelapa).

Kriteria skoring tekstur: 1 (sangat tidak renyah), 2 (tidak renyah), 3 (agak renyah), 4 (renyah), 5 (sangat renyah).

\section{Warna}

Warna merupakan atribut sensoris yang pertama dapat diamati. Warna bisa dijadikan parameter pertama yang menentukan ketertarikan pada suatu produk makanan. Hasil sidik ragam menunjukkan bahwa penambahan blondo pada flakes tepung beras merah memberikan pengaruh nyata $(\mathrm{P}<0,05)$ terhadap kesukaan panelis. Seperti yang terlihat pada Tabel 10 Nilai kesukaan terhadap warna flakes tepung beras merah yang tertinggi terdapat pada P0 (blondo 0\%) yaitu 4,28 (agak suka) dan yang terendah terdapat pada P5 (blondo 70\%) yaitu 3,16 (biasa).

\section{Aroma}

Hasil sidik ragam menunjukkan bahwa penambahan blondo pada flakes tepung beras merah berpengaruh nyata $(\mathrm{P}<0,05)$ terhadap aroma flakes tepung beras merah dengan uji skoring. Skor aroma tertinggi diperoleh pada perlakuan P5 (blondo 70\%) yaitu 4,68 dengan kriteria sangat khas kelapa, sedangkan skor terendah diperoleh pada perlakuan P0 (blondo 0\%) yaitu 2,40 dengan 
kriteria tidak khas kelapa. Blondo memiliki aroma kelapa, sehingga semakin banyaknya penambahan blondo maka aroma kelapa pada flakes tepung beras merah meningkat. Uji hedonik aroma pada flakes tepung beras merah menunjukkan bahwa dengan adanya penambahan blondo memberikan pengaruh yang tidak nyata $(\mathrm{P}>0,05)$.

\section{Rasa}

Hasil sidik ragam menunjukkan bahwa penambahan blondo pada flakes tepung beras merah berpengaruh nyata $(\mathrm{P}<0.05)$ terhadap rasa flakes tepung beras merah dengan uji skoring. Tabel 6 menunjukkan bahwa flakes yang memperoleh skor rasa tertinggi adalah perlakuan P5 (blondo 70\%) yaitu 4,52 dengan kriteria sangat khas kelapa, sedangkan skor rasa terendah diperoleh pada perlakuan P0 yaitu 2,08 dengan kriteria tidak khas kelapa. Panelis mengatakan bahwa penambahan blondo pada flakes tepung beras merah meningkat seiring dengan meningkatnya konsentrasi penambahan blondo. Hal tersebut dikarenakan rasa kelapa yang ada pada blondo. Hasil sidik ragam terhadap uji hedonik flakes tepung beras merah dengan penambahan blondo menunjukkan pengaruh yang tidak nyata $(\mathrm{P}>0,05)$.

\section{Tekstur}

Hasil sidik ragam menunjukkan bahwa penambahan blondo pada flakes tepung beras merah memberikan pengaruh yang berbeda nyata $(\mathrm{P}<0,05)$. Tabel 6 menunjukkan bahwa skor tekstur tertinggi diperoleh pada perlakuan P0 (blondo 0\%) yaitu 4,96 dengan sangat kriteria renyah, sedangkan skor tekstur terendah diperoleh pada perlakuan P5 (blondo 70\%) yaitu 2,84 dengan kriteria agak renyah. Panelis mengatakan bahwa semakin tinggi nya penambahan konsentrasi blondo pada flakes tepung beras merah maka tingkat kerenyahan flakes tepung beras merah menurun. Hal tersebut dikarenakan kadar air pada flakes tepung beras merah yang semakin meningkat dengan meningkatnya konsentrasi penambahan blondo. Blondo memiliki kadar air sebesar 40,88\%. Kadar air pada bahan pangan merupakan komponen yang penting, karena kadar air dapat mempengaruhi penampakan, tekstur dan cita rasa makanan (Winarno, 1995).

\section{Penerimaan Keseluruhan}

Hasil sidik ragam menunjukkan bahwa penambahan blondo pada flakes tepung beras merah memberikan pengaruh yang tidak nyata $(\mathrm{P}>0,05)$ terhadap penerimaan keseluruhan dengan uji hedonik. Seperti yang disajikan pada Tabel 5 . Rata-rata uji hedonik pada flakes tepung beras merah dengan penambahan blondo yaitu dengan kriteria agak suka.

\section{KESIMPULAN}

Berdasarkan hasil penelitian ini dapat disimpulkan bahwa penambahan blondo berpengaruh nyata terhadap kadar air, kadar protein, kadar lemak, kadar karbohidrat, kadar serat kasar, daya serap air, hedonik warna, skoring aroma, skoring rasa dan skoring tekstur.

Penambahan blondo yang menghasilkan flakes tepung beras merah dengan karakteristik terbaik yaitu pada penambahan blondo $40 \%$ 
dengan kriteria kadar air 3,58\%, kadar abu 1,62\%, kadar protein 10,97\%, kadar lemak 13,76\%, kadar karbohidrat 70,07\%, kadar serat kasar 4,21\%, daya serap air 43,25\%, warna agak suka, aroma agak khas kelapa dan agak suka, rasa agak khas kelapa dan agak suka, tekstur renyah dan agak suka dan penerimaan keseluruhan agak suka.

\section{UCAPAN TERIMAKASIH}

Penulis ingin menyampaikan terima kasih sebesar-besarnya kepada Program Studi Teknologi Pangan, Fakultas Teknologi Pertanian, dosen pembimbing dan rekan-rekan yang telah membantu proses penelitian hingga penyelesaian penulisan ini.

\section{DAFTAR PUSTAKA}

Anonimus. (1996). SNI 01-4270-1996. Syarat Mutu Flakes. Jakarta. Badan Standarisasi Nasional.

Anonimus. (2018). Data Komposisi Pangan Indonesia. Diakses tanggal 10 Oktober 2020.

Baik, B. K., Powers J. and Nguyen L.T. (2004). Extrusion of regular and waxy barley flours for production of expanded cereal. Journal Cereal Chemistry. 81 (1):94-99.

deMan J. M. (1997). Kimia Makanan. Penerjemah K. Padmawinata. Institut Teknik Bandung, Bandung.

Dewi, I A.A.S.P., I G.A Ekawati dan I D.P.K. Pratiwi. (2018). Pengaruh penambahan millet (Panicum milliaceum) terhadap karakteristik flakes. Jurnal Ilmu dan Teknologi Pangan. 7(4):175-183.

Dewi, S. K. (2008). Pembuatan Produk Nasi Instan Berbasis Fermented Cassava Flour sebagai Bahan Pangan Alternatif. Skripsi. Fakultas Teknologi Pertanian IPB, Bogor.

Diyah, N. W., Purwanto, Y. Susanti dan Y. K. Dewi. (2010). Pembuatan minyak kelapa secara enzimatis dengan memanfaatkan kulit buah dan biji pepaya serta analisis sifat fisikokimianya. Berkala Penelitian Hayati. 15 :181-185.
Febriandi, E., R. Sjarief dan S. Widowati. (2017). Studi sifat fungsional padi lokal (mayang pandang) pada berbagai tingkat drajat sosoh. Jurnal Penelitian Pasca Panen Pertanian. 14 (2):79-87.

Gandhi, K. and Wenk R.S. 2012. Ready-to-eat cereal flakes containing legumes. US Patent WO2012170458 A1.

Gisca, I. D. B., dan A. Rahayuni. (2013). Penambahan gembili pada flakes jewawut ikan gabus sebagai alternatif makanan tambahan anak gizi kurang. Journal of Nutrition College. 2 (4):505-513.

Gomez, K. A. dan A. A. Gomez. (1995). Prosedur Statistik untuk Penelitian Pertanian. UI Press, Jakarta.

Hernawan, E. dan V. Melyani. (2016). Analisis karakteristik fisikokimia beras putih, beras merah dan beras hitam (Oryza sativa L., Oryza nivara dan Oryza sativa L. indica). Jurnal Kesehatan Bakti Tunas Husada. 15 (1): 79-91.

Komala, A., Yusmarini dan Rahmayuni. (2017). Kajian pemanfaatan tepung sukun dan tepung ampas kelapa dalam pembuatan flakes. SAGU. 16: 1412-4424.

Murtius, W.S. (2008). Pemanfaatan Blondo Sebagai Starter Dalam Pembuatan Minuman Probiotik. Thesis. Program Pasca Sarjana Universitas Andalas, Padang.

Nindyawati, L., P.T. Ina dan A.A.I.S. Wiadnyani. (2019). Pengaruh Penambahan Kentang Kukus dan Tepung Kacang Hijau (Phaseolus radiatus L.) Terhadap Karakteristik Flakes. Jurnal Ilmu dan Teknologi Pangan. 8 (1):6674.

Permana, R. A. dan W. D. R. Putri. (2015). Pengaruh proporsi jagung dan kacang merah serta substitusi bekatul terhadap karakteristik fisik kimia flakes. Jurnal Pangan dan Agroindustri. 3 :734-742.

Prianggi, A. D., P. A. S. Widpradnyadewi dan N. W. Wisaniyasa. (2017). Pengaruh substitusi terigu dengan buah lindur (Bruguiera gymnorrhiza L.) terhadap karakteristik flakes. Jurnal Ilmu dan Teknologi Pangan. 5 (2):51-63.

Purba, J. E., R. J. Nainggolan dan Ridwansyah. (2017). Karakterisasi sifat fisiko kimia dan sensori cookies dari tepung komposit (beras merah, kacang merah dan mocaf). Jurnal Rekayasa Pangan dan Pertanian. 5 (2):301 309. 
Rahmadani, K. A., N. W. Wisaniyasa dan P.A. Sandhi. (2016). Pengaruh perbandingan kentang kukus dengan terigu terhadap karakteristik flakes. Jurnal Ilmu dan Teknologi Pangan. 5 (1):26-36.

Richana, R. dan T.C. Sunarti. (2004). Karakterisasi sifat fisiko kimia tepung umbi dan tepung pati dari umbi ganyong, suweg, ubi kelapa, dan gembili. Jurnal Pasca panen. 1(1): 29-37.

Santoso A. (2011). Serat Pangan (Dietary Fiber) dan Manfaatnya Bagi Kesehatan. Magistra. $23(75): 35-40$.

Setiaji, B. dan S. Prayugo. (2006). Membuat VCO Berkualitas Tinggi. Penebar Swadaya, Jakarta.

Soekarto, S. T. (1985). Penilaian Organoleptik (untuk Industri Pangan dan Hasil Pertanian). Penerbit Bharata Karya Aksara, Jakarta.

Sudarmadji, S., B. Haryono dan Suhardi. (1997). Prosedur Analisa Untuk Bahan Makanan dan Pertanian. Liberty, Yogyakarta.

Sugandhi, M. Z., D. Z. Arief dan T. Widiantara. (2016). Pengaruh perbandingan tepung biji kacang koro pedang (Canavalia Ensiformis) terhadap karakteristik flakes. Skripsi. Fakultas Teknik Universitas Pasundan, Bandung.

Susanto, T. (2012). Kajian metode pengasaman dalam proses produksi minyak kelapa ditinjau dari mutu produk dan komposisi asam amino blondo. Jurnal Dinamika Penelitian Industri. 23:124-130.

Tahir, M. M., M. Mahendradatta dan A. Mawardi. (2018). Studi pembuatan kue kering dari tepung sagu dengan penambahan tepung blondo. Jurnal Teknologi Pangan. 11 (2): 7080.

Umar, M. I., Ansarullah dan M. Syukri. (2018). Pengaruh formulasi breakfast cereal flakes berbasis tepung beras merah (Oryza nivara) dan tepung sagu (Metroxylon $s p$ ) terhadap penilaian organoleptik dan fisikokimia. Jurnal Sains dan Teknologi Pangan. 3 :1176-1193.

Utama, I G. D. A., N. W. Wisaniyasa dan I W. R. Widarta. (2019). Pengaruh perbandingan terigu dengan tepung kecambah jagung (Zea mays L.) terhdap karakteristik flakes. Jurnal Ilmu dan Teknologi Pangan. 8 (2):140-149.

Widodo, S. (2007). Pemanfaatan Limbah Virgin Coconut Oil (Blondo) dalamPembuatan MPASI (Biskuit Bergizi). Thesis. Tidak dipublikasikan. Pascasarjana Universitas Hasanuddin, Makassar.
Widodo, S. (2015). Peningkatan Status Gizi Anak Balita Gizi Kurang (3-5 tahun) Melalui Pemberian Biskuit Padat Gizi Berbasis Blondo, Tepung Ikan Gabus dan Tepung Beras Merah di Kota Pare-pare Propinsi Sulawesi Selatan. Disertasi. Tidak dipublikasikan. Pascasarjana Institut Pertanian Bogor, Bogor. 